\title{
Atmospheric particulate mercury at the urban and forest sites in central Poland
}

\author{
Patrycja Siudek $^{1} \cdot$ Marcin Frankowski $^{1} \cdot$ Jerzy Siepak $^{2}$
}

Received: 29 June 2015 / Accepted: 21 September 2015 / Published online: 28 September 2015

(C) The Author(s) 2015. This article is published with open access at Springerlink.com

\begin{abstract}
Particulate mercury concentrations were investigated during intensive field campaigns at the urban and forest sites in central Poland, between April 2013 and October 2014. For the first time, quantitative determination of total particulate mercury in coarse $\left(\mathrm{PHg}_{2.2}\right)$ and fine $\left(\mathrm{PHg}_{0.7}\right)$ aerosol samples was conducted in Poznań and Jeziory. The concentrations in urban fine and coarse aerosol fractions amounted to $<\mathrm{MDL} \pm 77.1 \mathrm{pg} \mathrm{m}^{-3}$ and $<\mathrm{MDL} \pm$ $604.9 \mathrm{pg} \mathrm{m}^{-3}$, respectively. Aerosol samples collected during the whole study period showed statistically significant differences for particulate mercury concentrations. A strong impact of meteorological conditions (wind velocity, air mass direction, air temperature, and precipitation amount) on particulate mercury concentrations was also observed. In particular, higher variation and concentration range of $\mathrm{PHg}_{0.7}$ and $\mathrm{PHg}_{2.2}$ was reported for wintertime measurements. An increase in atmospheric particulate mercury during the cold season in the study region indicated that coal combustion, i.e., residential and industrial heating, is the main contribution factor for the selected particle size modes. Coarse particulate $\mathrm{Hg}$ at the urban site during summer was mainly attributed to anthropogenic sources, with significant contribution from resuspension processes and long-range transport. The highest values of $\mathrm{PHg}_{0.7}$ and $\mathrm{PHg}_{2.2}$ were found during westerly and
\end{abstract}

Responsible editor: Philippe Garrigues

Patrycja Siudek

pat.s@amu.edu.pl

1 Department of Water and Soil Analysis, Faculty of Chemistry, Adam Mickiewicz University in Poznań, Umultowska 89b Street, 61-614 Poznań, Poland

2 Hipolit Cegielski State College of Higher Education in Gniezno, 38 ks. Kard. Stefana Wyszynskiego Street, 62-200 Gniezno, Poland southerly wind events, reflecting local emission from highly polluted areas. The period from late fall to spring showed that advection from the southern part of Poland was the main factor responsible for elevated $\mathrm{Hg}$ concentrations in fine and coarse particles in the investigated region. Moreover, September 2013 could be given as an example of the influence of additional urban activities which occurred approx. $10 \mathrm{~m}$ from the sampling site - construction works connected with replacement of the road surface, asphalting, etc. The concentrations of particulate $\mathrm{Hg}\left(>600.0 \mathrm{pg} \mathrm{m}^{-3}\right)$ were much higher than during the following months when any similar situation did not occur. Our investigations confirmed that $\mathrm{Hg}$ in urban aerosol samples was predominantly related to local industrial and commercial emissions, whereas the main source of $\mathrm{Hg}$ in particulate matter collected at the forest site was connected with regional anthropogenic processes. This paper provides the results of the first long-term measurements of sizefractionated particulate mercury conducted in central Poland, which could be an important insight into atmospheric Hg processes within such a scarcely investigated part of Europe.

Keywords Particulate mercury · Urban · Forest · Seasonal variation $\cdot$ Dry deposition $\cdot$ Poland

\section{Introduction}

Atmospheric chemistry of mercury is associated with a variety of natural and anthropogenic sources, among which local, regional, and global industrial and urban activities (coal combustion processes) play the most important role (Pacyna et al. 2010). Gaseous elemental mercury $\left(\mathrm{GEM}\right.$ or $\left.\mathrm{Hg}^{\circ}\right)$ is the predominant form of $\mathrm{Hg}$ in the atmosphere ( $>95 \%$ of total gaseous mercury (TGM), Ebinghaus et al. 1999), with residence time of about 1 year (Schroeder and Munthe 1998). The other 
$\mathrm{Hg}$ species which are present in the ambient air include oxidized and reactive gaseous mercury (GOM, RGM) and total particulate-phase species (TPM, PHg). They together constitute less than $5 \%$ of TGM. Both these forms are less volatile, more water-soluble, and more chemically reactive than GEM and have much shorter atmospheric lifetime (i.e., minutes to weeks). Therefore, their vertical distribution in the troposphere is often limited to emission areas due to rapid removal processes via dry and wet deposition (Lindberg et al. 2007). However, depending on their chemical and photochemical transformations with oxidizing precursors as well as on the meteorological effects (turbulent mixing, inversion layer, entrainment of dry air), gaseous and particulate mercury usually vary significantly as a function of time and space.

Despite the significant decrease of total gaseous mercury registered at many background monitoring sites, urban environments are still regarded as hotspots in the regional and global budget of $\mathrm{Hg}$ (Xu et al. 2015). In recent years, field measurements from highly polluted regions in Asia (Fang et al. 2010; Fu et al. 2011; Zhu et al. 2014; Jen et al. 2014; $\mathrm{Xu}$ et al. 2015; Zhang et al. 2015), USA (Lynam and Keeler 2006; Rutter et al. 2009; Liu et al. 2010; Lynam et al. 2014) and Europe (Li et al. 2008), as well as multi-scale model analysis (Bieser et al. 2014; De Simone et al. 2014; Gencarelli et al. 2014) showed relatively high spatial and seasonal variability in concentrations of atmospheric particulate mercury. Furthermore, different source apportionment analyses (e.g., receptor model, hybrid chemical transport, positive matrix factorization) of speciated atmospheric mercury at most of those sites demonstrated a sharp increase in PHg as a result of anthropogenic emission from local point/non-point sources including refineries, iron/steel manufacturing sites, power and chemical plants, coal-fired utilities, and road traffic (Cheng et al. 2013; Li et al. 2008; Zhang et al. 2015). In addition, the influence of high-temperature processes associated with residential and industrial heating during cold season was emphasized in the abovementioned works. For example, extremely high values of total particulate $\mathrm{Hg}$ concentrations $\left(8407 \mathrm{pg} \mathrm{m}^{-3}\right)$ were observed in the city of Guiyang, one of the most polluted areas in China, which reflected a large contribution of urban activities, such as residential coal burning and smelting (Fu et al. 2011).

The long-term $\mathrm{Hg}$ measurements in central and eastern Europe are still limited. So far, the observations of speciated atmospheric mercury (wet and dry deposition) in Poland have been conducted only in the urbanized coastal zone of the southern Baltic (Beldowska et al. 2012; Siudek et al. 2015), in the Upper Silesia region (Pyta et al. 2009), and at the single rural site in southern Poland (Zielonka et al. 2005). Siudek et al. (2011) studied the variability of total particulate mercury (TPM) in Gdynia (northern Poland) over the 1-year study period in 2008-2009, using the Principal Component Analysis method, and found large wintertime fluctuations of $\mathrm{Hg}$ both in fine and coarse aerosol fractions, with the mean value of $4.1 \pm 6.7 \mathrm{pg} \mathrm{m}^{-3}$ and $35.5 \pm 28.5 \mathrm{pg} \mathrm{m}^{-3}$, for $\mathrm{TPM}_{0.7}$ and $\mathrm{TPM}_{2.2}$, respectively. These investigations provided a significant insight into pollution sources, atmospheric processes, seasonal patterns, and various factors controlling the concentrations of particulate mercury at urban sites. However, they did not provide data of reactive gaseous species (RGM). Although both the northern and southern parts of Poland have started atmospheric mercury field programs, there are still no reliable data of particle-bound mercury concentrations and dry deposition fluxes from industrialized and urbanized central regions such as Wielkopolska district. In this paper, we present the first long-term measurements of particulate mercury in the urban and forest sites in central Poland. The main purposes of this study were as follows: (1) examine seasonal variation of $\mathrm{PHg}_{0.7}$ and $\mathrm{PHg}_{2.2}$ within the two-point study domain, (2) identify main factors (chemical and meteorological) that affect particulate-phase mercury concentrations, (3) determine types of emission sources and factors responsible for seasonal variability in particulate-phase mercury, including urban and forest areas, and (4) estimate dry deposition fluxes of particulate mercury. We also compared our results with other urban/ industrial and remote/forest areas.

\section{Materials and methods}

\section{Study area}

Aerosol samples for mercury analysis were collected at two sites in Wielkopolska district (Poland) during the 1.5-year study period between April 2013 and October 2014. Poznań is the largest city in this region, with the population of about 700,000 (Fig. 1). The first sampling site was located in the Botanic Garden of Adam Mickiewicz University $\left(52^{\circ} 42^{\prime} \mathrm{N}\right.$, $16^{\circ} 88^{\prime} \mathrm{E}$, Fig. 1), approx. $2 \mathrm{~km}$ northwest from the city center of Poznań. The airport Poznań Ławica is located approx. $4 \mathrm{~km}$ west of this station. About $10 \mathrm{~km}$ northeast of the sampling site, there is a large coal-fired power plant-Karolin CFPP. In addition, within a radius of $30 \mathrm{~km}$ of Poznań, several major sources of $\mathrm{Hg}$ are located, i.e., dumping grounds for municipal wastes, low-capacity domestic heating units, sewage treatment plants, cement factories, industrial units producing metal and paints, smelters, waste incinerators, different manufactories, heavy traffic, and agricultural activities.

The second site was located in the Ecological Station of Adam Mickiewicz University in Jeziory (Fig. 1). This station is situated about $30 \mathrm{~km}$ southwest of Poznan Agglomeration, in the protected woodland area of the Wielkopolski National Park. Any particular local anthropogenic urban or industrial activities are not closer than within approx. $25 \mathrm{~km}$ of the site, and traffic emission is relatively low (medium-traffic road is about $4 \mathrm{~km}$ away). Hence, this sampling station can be 
Fig. 1 Location of both sampling sites: Poznań (a) and Jeziory (b) in Wielkopolska District, central Poland. The mixed forest has been indicated as green area

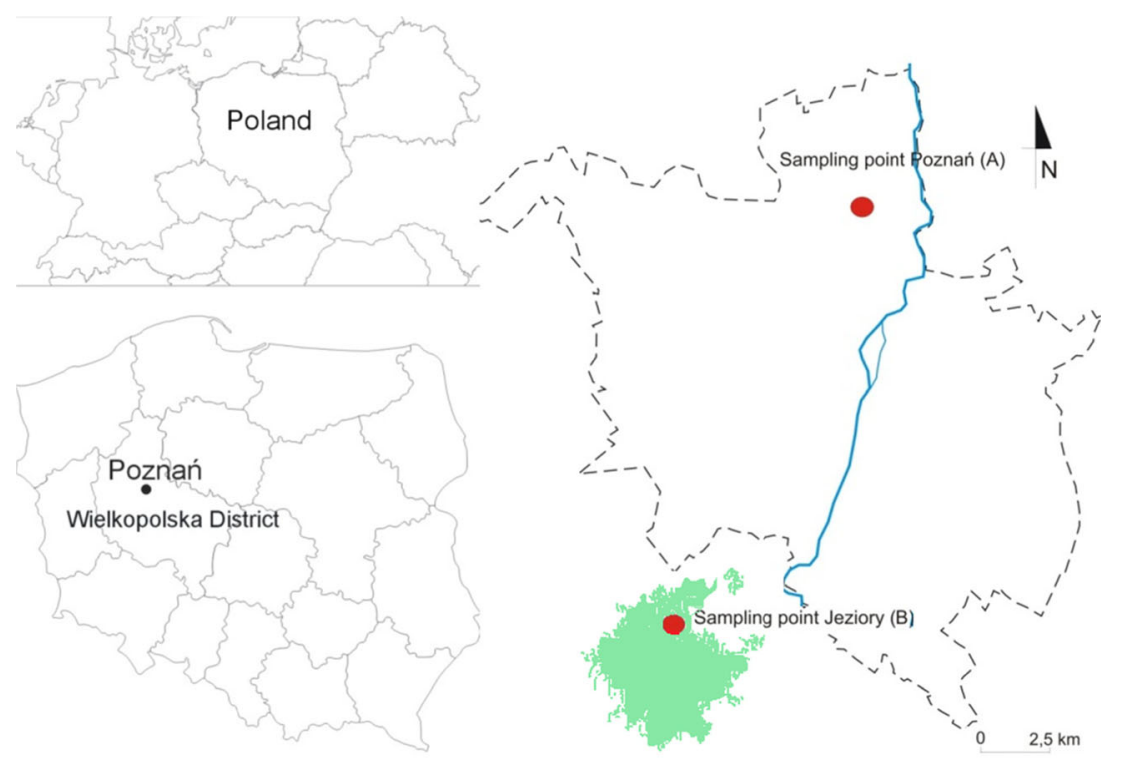

regarded as a regional background site for atmospheric mercury measurements.

\section{Sampling site and program}

In both locations, particulate mercury samples were collected using a low-volume sampler. The sampling system included oil-free vacuum pump, air flow gauge inside the sampling box, filter holder, and acid-cleaned open-faced Teflon filter pack installed at the 2-m sampling tower. Filters were loaded in a cascade (downward facing) and closed in a Teflon case.

The filter-based sampling system was used for the collection of particle-phase $\mathrm{Hg}$ samples onto two types of 47- mm filters: quartz-fiber filters (with pore size of $2.2 \mu \mathrm{m}$, for coarse particles collection, operationally defined as $\mathrm{PHg}_{2.2}$ or $\mathrm{Hg}_{\text {coarse}}$ ) and glass-fiber filters (with pore size of $0.7 \mu \mathrm{m}$, for fine particles collection, operationally defined as $\mathrm{PHg}_{0.7}$ or $\left.\mathrm{Hg}_{\text {fine }}\right)$. The sampler was operated at the average air flow rate of $30 \mathrm{~L} \mathrm{~min}{ }^{-1}$. Prior to sampling, quartz filters were precombusted for $5 \mathrm{~h}$ at $500{ }^{\circ} \mathrm{C}$ in a muffle furnace in order to remove all organic compounds. During the whole study period, a total number of 326 samples were collected at both sites using the same instrumentation; however, the aspiration time was different. At the POZ sampling site (urban area), the filter pack was prepared for a 24-h sampling period (typical aspiration cycle: 7 a.m. to 7 a.m. of the next sampling day), except for non-working days when a 72-h sampling procedure was applied. At the second station, in Jeziory, field measurements were carried out continuously for about a week. Such an approach was implemented in order to collect a measurable amount of particulate mercury as well as to maintain maximum efficiency of the sampling system and to improve the sensitivity of $\mathrm{Hg}$ detection. Different sampling durations at two sites could lead to some positive (RGM sorption or reaction with deposited solid phase on the filter) or negative (volatilization of unknown part of semi-volatile species through gas-particle conversion) artifacts, especially at the forest site. A detailed description of errors associated with long sampling time can be found elsewhere (Lynam and Keeler 2005). After sampling, filter samples were sealed in separated polyethylene zipped bags and stored at $-18^{\circ} \mathrm{C}$ until the main analysis.

The use of undenuded quartz filters made it impossible to estimate what percentage of gaseous $\mathrm{Hg}$ species (i.e., RGM) was retained during the aspiration period, due to lack of an attached $\mathrm{KCl}$-coated annular denuder to trap gas-phase $\mathrm{Hg}^{\circ}$ and $\mathrm{Hg}^{2+}$ from the sampled airstream. Therefore, based on the results from other observations, i.e., Lynam and Keeler (2002, 2005) and Landis et al. (2002), we can only speculate about possible uncertainties estimated during the particulate mercury sampling with a filter pack containing quartz filters. Lynam and Keeler (2005) reported a large spectrum of errors while determining particulate mercury concentrations in 10-, 14and 24-h duration samples collected onto quartz filters through the use of (i) $\mathrm{KCl}$ denuder (for $\mathrm{Hg}^{2+}$ removal), (ii) $\mathrm{KCl}$ and $\mathrm{KI}$ denuders (for $\mathrm{O}_{3}$ and $\mathrm{Hg}^{2+}$ removal), and (iii) without a denuder system. For example, they observed larger amounts of particulate mercury on denuded filters compared to undenuded ones for the majority of sampling days (Lynam and Keeler 2005). It was found that the maximum difference between denuded and undenuded filters was $33 \mathrm{pg} \mathrm{m}^{-3}$. Interestingly, results from the experiments with $\mathrm{KCl}$-coated denuders suggested that homogeneous or heterogeneous chemical reactions may take place inside a denuder during sampling, causing statistically significant net production of $\mathrm{Hg}$. The authors highlighted that RGM production may also occur in $\mathrm{KCl}$ denuders (Lynam and Keeler 2005). Moreover, comparison tests indicated that ozone can be scrubbed from 
$\mathrm{KCl}$ denuders and the efficiency of this mechanism decreases with the increase in ozone concentration (Lynam and Keeler 2005). All the artifacts mentioned above are mostly associated with higher photochemical activity and higher levels of oxidants in the atmosphere. The filter-based sampling approach is still one of conventional methods in particulate mercury investigations ( $\mathrm{Lu}$ et al. 1998) and has been applied by other groups of aerosol scientists in Poland during $\mathrm{Hg}$ measurement campaigns (Zielonka et al. 2005; Pyta et al. 2009; Siudek et al. 2011; Beldowska et al. 2012). In addition, there are some contradictory results that showed significantly higher amounts of particulate mercury collected on undenuded quartz filters as compared to those collected downstream of KCl-coated annular denuders (Lynam and Keeler 2002; Landis et al. 2002). In such cases, the observed artifacts were caused by a presence of $\mathrm{Hg}^{2+}$ which was absorbed by particulate matter.

It the present study, we did not perform any intercomparison experiments to quantify positive or negative artifacts between the conventional sampling methods (filter pack with quartz filters) and the methods with the use of $\mathrm{KCl}$ coated annular denuder (for reactive gaseous mercury removal). Therefore, while estimating total particle-bound $\mathrm{Hg}$, we did not discuss any uncertainties arisen from the lack of RGM separation by a KCl-coated denuder. The results of particulatephase mercury concentrations were obtained from both types of filters, representing the total particle-phase mercury $\left(\mathrm{Hg}_{\mathrm{p}}=\right.$ $\mathrm{PHg}_{0.7}+\mathrm{PHg}_{2.2}$ ).

\section{Analysis of $\mathrm{Hg}$ in particulate matter}

Mercury concentrations were quantitatively determined using a cold-vapor atomic fluorescence spectrometry (CVAFS, PSA 10.025 Millennium Merlin, UK) following EPA method 1631E (US EPA 2002). The instrument was optimized using five standard solutions $\left(5,10,15,20\right.$, and $50 \mathrm{ng} \mathrm{L}^{-1}$ of $\mathrm{Hg}$, $R^{2}>0.999$ ), prepared from a $\mathrm{HgNO}_{3}$ stock solution, to ensure stable conditions over the whole analytical procedure. An average recovery level of $\mathrm{Hg}_{\mathrm{p}}$ was $98.3 \pm 1.6 \%$, and the method precision (given as relative standard deviation) was found to be below $8 \%(n=6)$. The detection limit for the $\mathrm{Hg}_{\mathrm{p}}$ analysis, calculated as three times the standard deviation of a set of 10 analytical blanks, was $1.7 \mathrm{pg} \mathrm{m}^{-3}$. Prior to the analysis, filter samples were acid-digested $\left(10 \mathrm{~mL}\right.$ of $\left.60 \% \mathrm{HNO}_{3}\right)$ using the microwave digestion system (MARSXpress), in acid-cleaned Teflon vessels. The analytical QC/QA was performed using a series of blanks and calibration curves in order to evaluate any loss of $\mathrm{Hg}$ during the experiments. The series of field (the preloaded filter pack with quartz and glass-fiber filters, connected to the sampling system but without air pumping) and procedural blanks were analyzed in the same manner as environmental samples. Blank values corresponded, on average, to $1.8 \%$ of a sample value $(n=6)$. The value of the field blank was subtracted from total $\mathrm{Hg}_{\mathrm{p}}$ concentration measured in each sample. The collection, handling, transport, and storage did not introduce any significant artifacts.

\section{Backward trajectories and meteorological data}

The HYSPLIT model (Draxler and Rolph 2003, NOAA Air Resources Laboratory, Silver Spring, MD, USA) was used to study air masses passing over the study domain and to identify potential sources that emerged during the long-range transport of air parcels towards the sampling location. The input parameters were as follows: meteorological database - Global Data Assimilation System (GDAS, spatial resolution $1^{\circ}$ ), starting heights above ground level-500/1000/1500 m, trajectory duration-96-h, and the vertical motion based on model vertical velocity. The backward trajectories (BTs) of air parcels were generated at 6-h intervals (at 0:00 am, 6:00 am, 12:00 pm, and 6:00 pm) for each event.

The meteorological data considered in this paper included air temperature, relative humidity, atmospheric pressure, wind speed, and direction. All data were registered automatically using a meteo-station at both sampling sites. In general, average air temperature, pressure, and relative humidity in Poznań ranged between -5.7 and $23.6^{\circ} \mathrm{C}, 1000$ and $1008 \mathrm{hPa}, 76$ and $95 \%$, respectively. At the Jeziory station, in the period between April 2013 and October 2014, the values of air temperature were between -10.0 and $24.8^{\circ} \mathrm{C}$, relative humidity was $66 \%$, while the monthly mean pressure varied between 1000.7 and $1008.0 \mathrm{hPa}$.

Statistical analyses were performed through the use of Statistica v.10.0 software. The non-parametric Kruskal-Wallis test was applied to determine differences of $\mathrm{PHg}_{0.7}$ and $\mathrm{PHg}_{2.2}$ in relation to all seasons, i.e., spring (III-V), summer (VIVIII), fall (IX-XI), and winter (XII-II) and sites. Data were analyzed for the normality, and the outlier/extreme values were determined. For all tests, the $p$ value of $<0.05$ was considered as statistically significant.

A theoretical model was applied to calculate dry $\mathrm{Hg}$ deposition fluxes $\left(F_{d}\right.$ in $\mu \mathrm{g} \mathrm{m}^{-2}$ period $\left.^{-1}\right)$. Similar approach was previously used by Fang et al. (2010) and Wan et al. (2009).

\section{Results and discussion}

\section{Particulate mercury in central Poland: urban vs. forest site}

Results from a 1.5-year study period in Poznań and Jeziory represent the first insight into the atmospheric chemistry of particulate mercury over a polluted region in central Poland. During these field measurements, mean concentrations of size-fractionated particulate mercury, operationally defined as fine $\left(\mathrm{Hg}_{\text {fine }}\right)$ and coarse modes $\left(\mathrm{Hg}_{\text {coarse }}\right)$, demonstrated statistically significant differences at the sampling sites. This 
significance was confirmed by the Kruskal-Wallis test $(p<0.05)$. Specifically, at the POZ site, the median value of $\mathrm{Hg}$ concentration in coarse particles was four times higher compared to $\mathrm{Hg}$ in fine particles (Table 1).

At the urban sampling site, mercury concentrations in fine particles ranged from $<$ MDL to $77.1 \mathrm{pg} \mathrm{m}^{-3}$, with the average of $7.3 \pm 9.1 \mathrm{pg} \mathrm{m}^{-3}$. The $\mathrm{Hg}$ concentration in coarse particles was significantly higher at this site (mean value \pm SD $22.6 \pm$ $45.3 \mathrm{pg} \mathrm{m}^{-3}$ ). The $75 \%$ of $\mathrm{Hg}$ measurements obtained for coarse particles in Poznań had concentrations up to $31.3 \mathrm{pg} \mathrm{m}^{-3}$, whereas the upper quartile of $\mathrm{Hg}$ in fine particles corresponded to the values below $10.0 \mathrm{pg} \mathrm{m}^{-3}$ (Table 1). At the second site, in Jeziory, the mean $\pm \mathrm{SD}$ of $\mathrm{Hg}$ concentration in coarse and fine particles was $20.8 \pm 21.6 \mathrm{pg} \mathrm{m}^{-3}$ and $2.4 \pm$ $2.8 \mathrm{pg} \mathrm{m}^{-3}$, respectively. In addition, $90 \%$ of $\mathrm{Hg}_{\text {fine }}$ values were within the range of $0.2-8.3 \mathrm{pg} \mathrm{m}^{-3}$ at this site.

\section{Particulate mercury from other ground-based observations}

The strong contrast between concentrations of total particulate mercury over urban/industrial and rural/remote sites in Europe, USA, Canada, and Asia has been presented in Table 2.

The mean concentration of total particulate mercury in coarse aerosol samples from Poznań was higher than values reported for some urban locations. For instance, $\mathrm{Li}$ et al. (2008) noted that the mean 24-h particulate-phase mercury concentration over the polluted area in Göteborg, Sweden did not exceed $12.5 \pm 16.4 \mathrm{pg} \mathrm{m}^{-3}$. Similar results were also obtained from measurements in Toronto (mean $18.0 \mathrm{pg} \mathrm{m}^{-3}$, Song et al. 2009) and a slightly higher mean $\mathrm{Hg}_{\mathrm{p}}$ concentration value was found in Seoul (26.3 $\pm 42.6 \mathrm{pg} \mathrm{m}^{-3}$, Seo et al. 2012).

The average total $\mathrm{Hg}_{\mathrm{p}}$ concentration in Poznań was about six times lower than that observed at the urban site in Mexico City, Mexico (Rutter et al. 2009). Some other measurements from highly polluted megacities in Asia, e.g., Guiyang (Fu et al. 2011), Beijing (Wang et al. 2006), Changchun (Fang et al.
2004), Nanjing (Zhu et al. 2014), or USA, e.g., Detroit (Liu et al. 2010) and San Francisco Bay Area (Rothenberg et al. 2010), exhibited elevated levels and significantly higher variability of total particulate mercury as compared to the city of Poznan, which suggests a large contribution from different anthropogenic sources to the total $\mathrm{Hg}_{\mathrm{p}}$. Results from the abovementioned studies showed that the particulate fraction of atmospheric mercury was predominantly affected by local industrial emission (power plants, cement production, nonferrous refinery, metallurgical processes, waste incinerator, steel industry, rubber and aluminum plants, glass factory) and other non-point $\mathrm{Hg}$ sources. For example, at the sub-urban site in Xiamen, China, the $\mathrm{Hg}_{\mathrm{p}}$ concentrations varied between $<$ MDL and $2930 \mathrm{pg} \mathrm{m}^{-3}$, with the mean value of $174.4 \mathrm{pg} \mathrm{m}^{-3}$, and were mainly associated with industrial and vehicle emissions (Xu et al. 2015). Similarly, Xiu et al. (2009) measured significantly higher $\mathrm{Hg}$ concentrations in trafficoriginated particulate matter at the measurement site near a road $\left(20 \cdot 10^{3}\right.$ vehicles $\mathrm{hr}^{-1}$ in rush hour) in Shanghai, China, suggesting a large contribution from tailpipe exhaust, wear dust from tires or brake linings, and the resuspension of road dust. Levels of $\mathrm{Hg}_{\mathrm{p}}$ measured at our urban site were lower than those determined at several sites in the vicinity of a semiconductor manufacturing complex in Taiwan, with higher $\mathrm{Hg}_{\mathrm{p}}$ (0.26 $\mathrm{ng} \mathrm{m}^{-3}$ ) observed in summer (Jen et al. 2014).

As shown in Table 2, particulate matter samples collected at the Jeziory site had the same mean values of $\mathrm{Hg}$ concentrations as those reported by Poissant et al. (2005), however, slightly higher as compared to rural sites in San Francisco Bay Area, North America (Rothenberg et al. 2010) or in Dexter (Liu et al. 2010). Interestingly, the $\mathrm{Hg}_{\mathrm{p}}$ concentrations in Jeziory were on average two times lower in comparison with the remote polar site in Alert, Canada, where a significant increase of $\mathrm{Hg}_{\mathrm{p}}$ in the ambient air was observed under specific conditions during the AMDE, i.e., very low temperature ( $T=$ $-24.8^{\circ} \mathrm{C}$ ) and relatively high particle loadings (Steffen et al. 2014). Such conditions favor the partitioning of oxidized

Table 1 Statistical analysis of particulate mercury concentration $\left(\mathrm{pg} \mathrm{m}^{-3}\right)$ determined in fine and coarse aerosol samples at the sampling sites in Poznań (urban) and Jeziory (forest), between April 2013 and

October 2014. The MDL is the amount of particulate mercury below the method detection limit

\begin{tabular}{|c|c|c|c|c|}
\hline & \multicolumn{2}{|l|}{ Poznań } & \multicolumn{2}{|l|}{ Jeziory } \\
\hline & $\mathrm{Hg}_{\text {fine }}$ & $\mathrm{Hg}_{\text {coarse }}$ & $\mathrm{Hg}_{\text {fine }}$ & $\mathrm{Hg}_{\text {coarse }}$ \\
\hline Mean & 7.3 & 22.6 & 2.4 & 20.8 \\
\hline $\mathrm{SD}$ & 9.1 & 45.3 & 2.8 & 21.6 \\
\hline Median & 4.0 & 16.4 & 1.6 & 13.9 \\
\hline $\mathrm{Q}_{1}-\mathrm{Q}_{3}$ & $1.5-10.0$ & $8.3-31.3$ & $0.5-3.1$ & $6.3-30.4$ \\
\hline Range & $<\mathrm{MDL}-77.1$ & $<\mathrm{MDL}-604.9$ & $<$ MDL-16.1 & $<$ MDL-142.5 \\
\hline $5-95 \%$ quartile & $0.3-22.8$ & $2.3-76.5$ & $0.2-8.3$ & $1.4-62.8$ \\
\hline$n$ & 226 & 226 & 100 & 100 \\
\hline
\end{tabular}


Table 2 Comparison of particulate mercury measurements from various worldwide sites. $\mathrm{PHg}$ concentration values are in $\mathrm{pg} \mathrm{m}^{-3}$, sampling sites are labeled as follows: $(C)$ coastal, $(R)$ rural, $(R e)$ remote, $(U)$ urban, and $(F)$ forest

\begin{tabular}{|c|c|c|c|c|}
\hline Site & Site type & Season & $\mathrm{PHg}$ & Reference \\
\hline Poznań, Poland & $\mathrm{U}$ & April 2013-October 2014 & Coarse, <MDL-604.9@fine, <MDL-77.1 & This study \\
\hline Gdynia, Poland & $\mathrm{C} / \mathrm{U}$ & April 2008-April 2009 & Coarse,0.3-151.5@fine, 0.2-39.9 & Siudek et al. (2011) \\
\hline Gdynia, Poland & $\mathrm{U}$ & December 2007-December 2008 & $2-142$ & Beldowska et al. (2012) \\
\hline Detroit, USA & $\mathrm{U}$ & 2004 & $1.0-1345.2$ & Liu et al. (2010) \\
\hline Femman, Sweden & $\mathrm{U}$ & 2005 & $3.89-20.26$ & Li et al. (2008) \\
\hline Beijing, China & $\mathrm{U}$ & 2003-2004 & $180-3510$ & Wang et al. (2006) \\
\hline Toronto, Canada & $\mathrm{U}$ & December 2003-November 2004 & 21.5 & Song et al. (2009) \\
\hline Mexico City, Mexico & $\mathrm{U}$ & March 2006 & $187 \pm 300$ & Rutter et al. (2009) \\
\hline Xiamen, China & $\mathrm{U}$ & March 2012-February 2013 & 174.4 & Xu et al. (2015) \\
\hline Guiyang, China & $\mathrm{U}$ & August-December 2009 & $0-8407$ & Fu et al. (2011) \\
\hline Seoul, Korea & $\mathrm{U}$ & 2006 & $23.9 \pm 42.6$ & Seo et al. (2012) \\
\hline Toronto, Canada & $\mathrm{U}$ & December 2003-November 2004 & $14.2-39.2$ & Zhang et al. (2012) \\
\hline Changchun, China & $\mathrm{U}$ & 1999-2000 & 276 & Fang et al. (2004) \\
\hline Nanjing, China & $\mathrm{U}$ & June 2011-February 2012 & $320-2040$ & Zhu et al. (2014) \\
\hline San Francisco Bay Area, USA & $\mathrm{U}$ & 2008 & $80.8 \pm 283$ & Rothenberg et al. (2010) \\
\hline Jeziory, Poland & $\mathrm{F}$ & April 2013-October 2014 & $\begin{array}{l}\text { Coarse, } 20.8 \\
\text { fine, } 2.4\end{array}$ & This study \\
\hline Waldhof, Germany & $\mathrm{R}$ & 2009-2011 & $<0.4-262$ & Weigelt et al. (2013) \\
\hline Dexter, USA & $\mathrm{R}$ & 2004 & $1.0-90.56$ & Liu et al. (2010) \\
\hline St. Anicet, Canada & $\mathrm{R}$ & 2003 & $26 \pm 54$ & Poissant et al. (2005) \\
\hline Alert, Canada & Re & $2002-2011$ & 41.3 & Steffen et al. (2014) \\
\hline San Francisco Bay Area, USA & $\mathrm{R}$ & 2008 & $7.99 \pm 6.74$ & Rothenberg et al. (2010) \\
\hline
\end{tabular}

mercury from RGM to $\mathrm{Hg}_{\mathrm{p}}$. The range of total particulatebound mercury $(\leq 2.5 \mu \mathrm{m})$ observed during a 3-year measurement cycle at a rural background site in Germany (Weigelt et al. 2013) was higher than the values obtained at the forest site in this study.

In the present study, $\mathrm{Hg}_{\text {coarse }}$ was predominant at both sites and constituted, on average, 76 and $90 \%$ of $\mathrm{Hg}_{\mathrm{p}}$ in Poznań and Jeziory, respectively. This was slightly lower as compared to the data reported for Gdynia by Beldowska et al. (2012). They found the $\mathrm{Hg}_{\text {coarse }} / \mathrm{Hg}_{\mathrm{p}}$ ratio to be 0.93 . This result can be explained by much higher contribution of $\mathrm{Hg}$ adsorbed onto sea-salt aerosols, which were directly emitted from bursting bubbles and breaking waves (Beldowska et al. 2012). During our 1.5-year study, the urban/forest ratio of mean $\mathrm{Hg}_{\text {coarse }}$ and $\mathrm{Hg}_{\text {fine }}$ concentrations was calculated to be 1.1 and 3.0, respectively, indicating a significant role of fine particles in atmospheric mercury transformations in Poznań. Recent studies by Liu et al. (2010) showed a twofold higher median $\mathrm{Hg}_{\mathrm{p}}$ concentration at the urban site (Detroit) than at the rural site (Dexter), indicating a significant impact of urban/ industrial areas on less polluted surrounding regions.

\section{Seasonal variations in the concentration of particulate mercury}

Figure 2 shows monthly average concentrations of $\mathrm{Hg}_{\mathrm{p}}$ at both examined sites in central Poland, between April 2013 and October 2014. The seasonal variability of $\mathrm{Hg}_{\mathrm{p}}$ concentration in coarse particles at both locations was quite similar. However, $\mathrm{Hg}_{\text {coarse }}$ values determined for Poznań were significantly higher (Kruskal-Wallis test, $p=0.001$ ). Specifically, the period of elevated mercury concentrations in coarse particles corresponded to the fall season of 2013 (mean $46.1 \mathrm{pg} \mathrm{m}^{-3}$ ) and the winter season of 2013/2014 (mean $42.3 \mathrm{pg} \mathrm{m}^{-3}$ ), whereas the lowest values of $\mathrm{Hg}_{\text {coarse }}$ were found in summer 2013 (mean $8.3 \mathrm{pg} \mathrm{m}^{-3}$ ). The same seasonal trend was observed for fine particulate $\mathrm{Hg}$ in Poznań, with mean $\mathrm{Hg}_{\text {fine }}$ concentrations of 7.3 and $5.2 \mathrm{pg} \mathrm{m}^{-3}$, respectively in winter and summer (Fig. 2). These differences were statistically significant $(p<0.05)$. In 2014, the highest mean concentration of $\mathrm{Hg}$ in coarse particles was observed in January at the urban site $\left(48.1 \mathrm{pg} \mathrm{m}^{-3}\right)$, while the monthly minimum was found in July $\left(9.3 \mathrm{pg} \mathrm{m}^{-3}\right)$. Moreover, the results from this site showed clear seasonal changes. The independent means $t$ test $(t=$ 6.301758, $\mathrm{df}=63, p<0.05)$ confirmed that differences in mean 


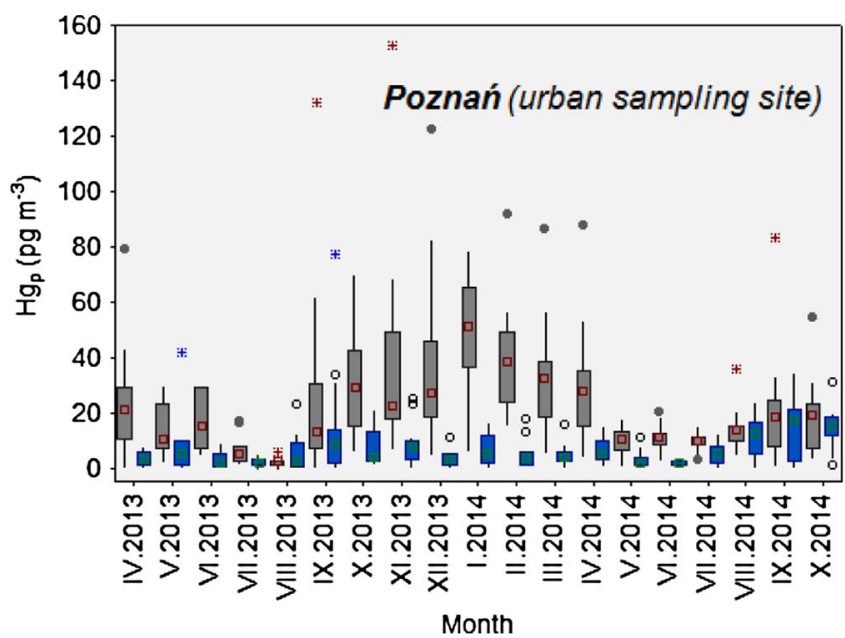

Fig. 2 Seasonal variation of monthly particulate mercury concentrations $\left(\mathrm{pg} \mathrm{m}^{-3}\right)$ in Poznan (left) and Jeziory (right), between April 2013 and October 2014. The $\mathrm{Hg}_{\text {coarse }}$ is indicated with gray box-whisker diagram

concentrations of $\mathrm{Hg}_{\text {coarse }}$ between warm and cold seasons of 2014 were statistically significant. These inter-seasonal variations in the atmospheric chemistry of $\mathrm{Hg}$, registered at the POZ sampling site, could be partly explained by substantial changes in meteorological conditions, i.e., differences in air temperature and humidity, variable wind speed and direction, turbulent diffusion rates, height of the mixing layer, and strength of various emission sources. For instance, higher concentrations of $\mathrm{Hg}_{\text {coarse }}$ in the period between October 2013 and February 2014 corresponded mostly to lower air temperatures. The negative correlation $(R=0.63)$ between $\mathrm{Hg}_{\text {coarse }}$ $\left(>30.0 \mathrm{pg} \mathrm{m}^{-3}\right)$ and ambient air temperature $\left(T_{\text {air }}\right.$ range -9.4 to $-1.1^{\circ} \mathrm{C}$ ) was found in February 2014. It was previously observed that low temperature is an important factor in atmospheric $\mathrm{Hg}$ transformations, and it enhances gas-to-particle conversion through the condensation and coagulation of combustion compounds onto aerosol surface (Kim et al. 2012).

In Poznan, the combustion of fossil fuels for domestic heating and power plants seems to be a key process responsible for notable increases in the concentration of $\mathrm{Hg}$ in particulate matter. The intensive hard coal combustion in lowcapacity domestic heating units (DHU) during heating season was previously identified as a main contributor of speciated atmospheric mercury at urban and rural sites in Poland. For example, Zielonka et al. (2005) registered high emissions of $\mathrm{Hg}(0.073 \mathrm{~kg})$ from these sources, which resulted in the extremely high value of $\mathrm{Hg}_{\mathrm{p}}$ dry deposition $\left(43.8 \mu \mathrm{g} \mathrm{m}^{-2}\right)$ during the short-term wintertime measurements (Jan 26-Feb 3, 2004) in Lichwin.

Based on the relationship between $\mathrm{Hg}_{\mathrm{p}}$ and the wind profile, it was noticed that under less turbulent atmospheric conditions (wind speed $1-2 \mathrm{~m} / \mathrm{s}$ ), the local sources effectively contributed to the increase in concentrations of $\mathrm{Hg}$ in aerosol samples. Specifically, meteorological situations associated with high frequency of western, southwestern, and southern

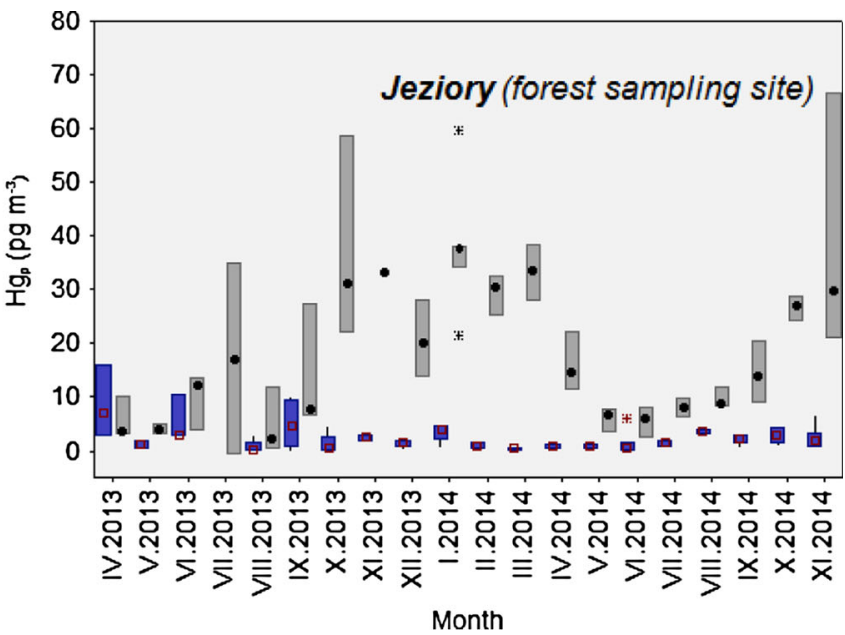

and $\mathrm{Hg}_{\text {fine }}$ with blue. The extreme values measured in Poznań (604.9 $\mathrm{pg} \mathrm{m}^{-3}$, September 2013) and Jeziory (142.5 $\mathrm{pg} \mathrm{m}^{-3}$, September 2013) have been excluded

advections towards the sampling site in Poznań, mostly in January and February 2014 (65 and $92 \%$ of observations), strongly corresponded to high $\mathrm{Hg}_{\mathrm{p}}$ concentrations measured in particulate matter samples from these months. In the same period, when northerly and northwesterly winds of medium $(1.0-3.0 \mathrm{~m} / \mathrm{s})$ or high velocity $(>3.0 \mathrm{~m} / \mathrm{s})$ occurred (on average $6.6 \%$ of cases), the concentration of $\mathrm{Hg}$ in coarse and fine particles declined by $\sim 10-25 \%$ in relation to samples collected during the W-SW-S advection.

Heterogeneous chemical transformations with other chemical species, i.e., $\mathrm{O}_{3}, \mathrm{SO}_{2}, \mathrm{CO}$, PAHs, BTX, radicals, and $\mathrm{Pb}$, were another factor that affected the seasonal variability of particle-bound Hg over the urban site (WIOŚ 2013). During the heating season (Oct-March), high Hg concentrations measured in coarse aerosol samples from Poznań were well correlated with $\mathrm{SO}_{2}(R=0.80)$, suggesting the same anthropogenic source of both species, i.e., coal combustion. These observations are in good agreement with data obtained from other urban and traffic sites where elevated values of particle-bound $\mathrm{Hg}$ in the ambient atmosphere clearly coincided with high concentrations of other anthropogenic pollutants (Lynam and Keeler 2006; Xu et al. 2015). Moreover, the analysis of concentrations in relation to working/non-working days in Poznań (not shown) revealed that the average values of $\mathrm{Hg}_{\mathrm{p}}$ concentrations determined in weekday samples were significantly different from those measured in samples collected during weekends (Kruskal-Wallis test, $p<0.01$ ).

In contrast to our urban site, the $\mathrm{Hg}_{\text {fine }}$ concentrations measured in Jeziory, which represents a relatively unpolluted region, did not exhibit a clear seasonal trend (Fig. 2b). Monthly concentrations of fine and coarse particulate $\mathrm{Hg}$ were within the ranges of $0.4-3.3 \mathrm{pg} \mathrm{m}^{-3}$ and $16.1-38.3 \mathrm{pg} \mathrm{m}^{-3}$, respectively. The highest concentration of $\mathrm{Hg}_{\text {coarse }}$ was measured in January 2014 (non-growing season), mainly as an effect of weather conditions, i.e., low wind speed $(<1 \mathrm{~m} / \mathrm{s})$ and high 
a

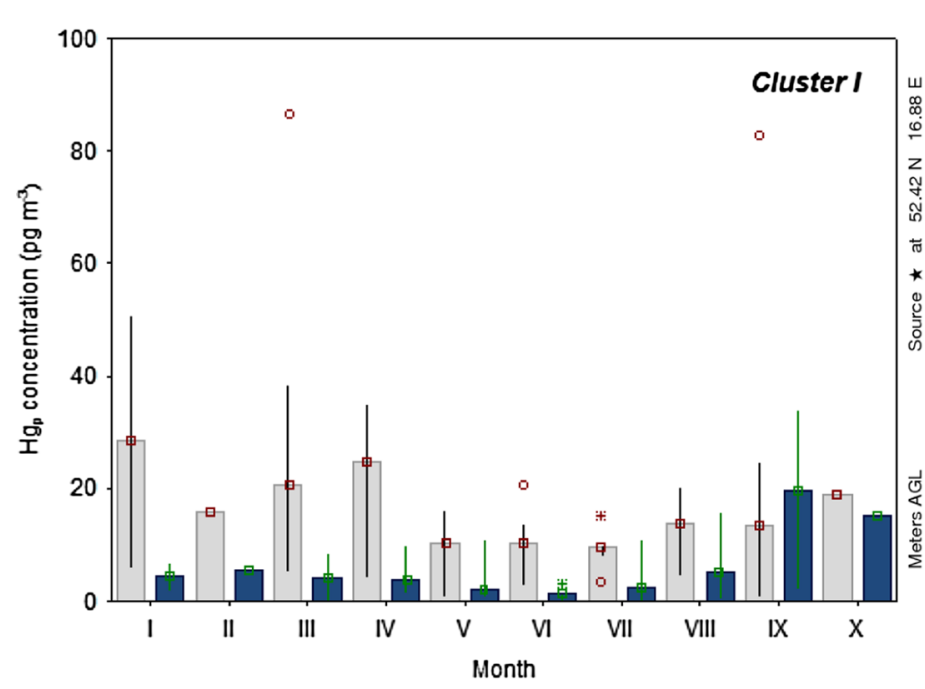

b

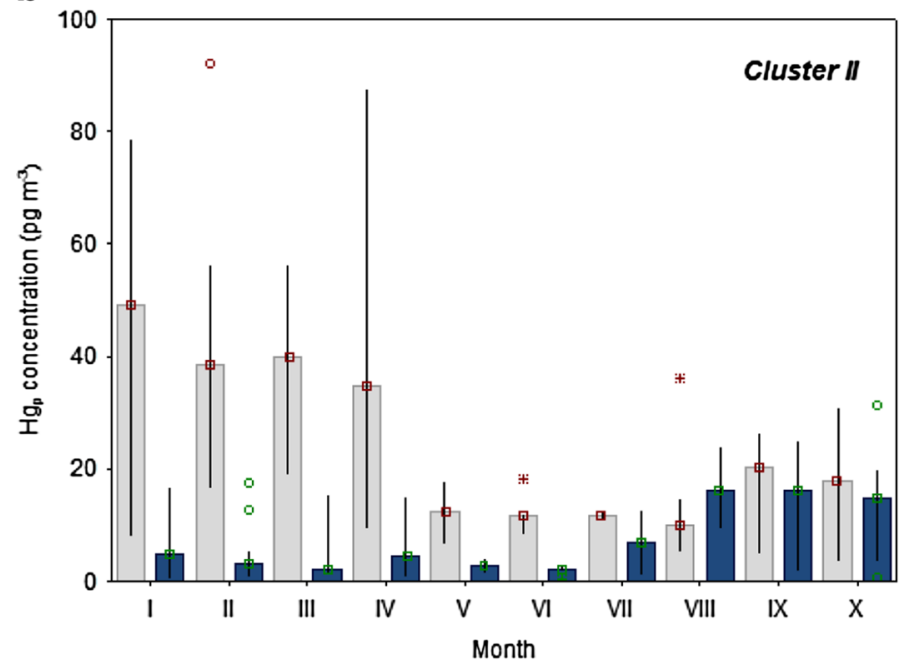

C

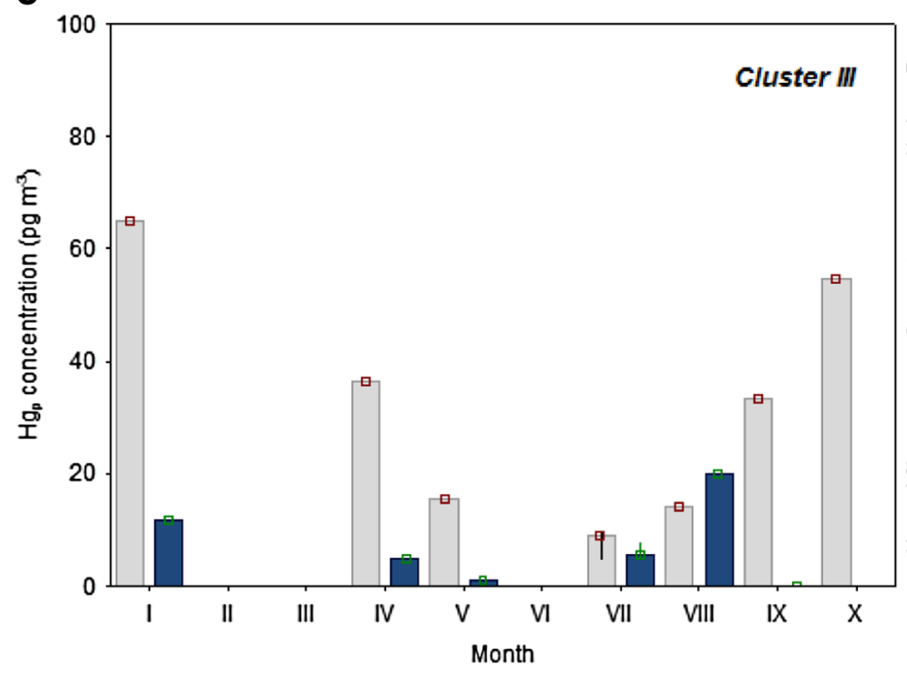

NOAA HYSPLIT MODEL

Backward trajectories ending at 0800 UTC 14 Jun 14 GDAS Meteorological Data

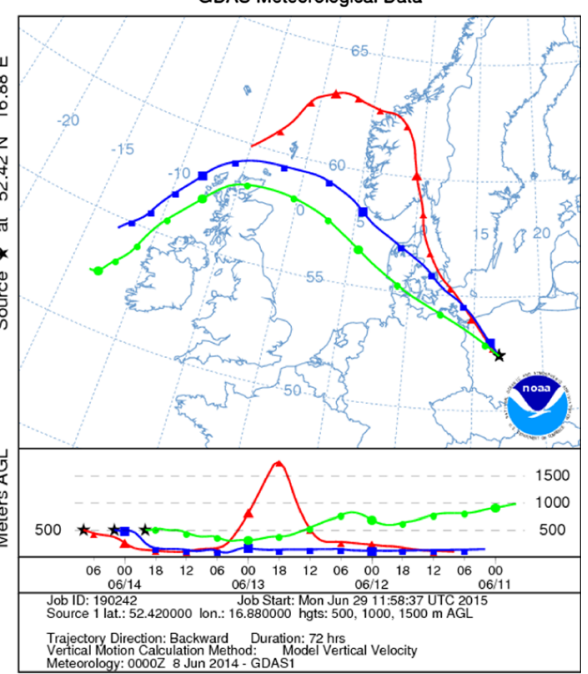

NOAA HYSPLIT MODEL

Backward trajectories ending at 0800 UTC 14 Jan 14 GDAS Meteorological Data

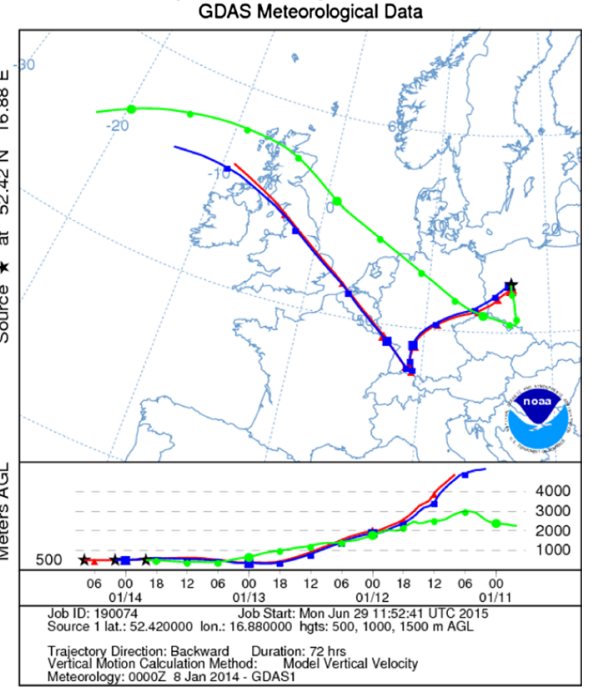

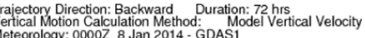

NOAA HYSPLIT MODEL

Backward trajectories ending at 0800 UTC 25 Apr 14 GDAS Meteorological Data

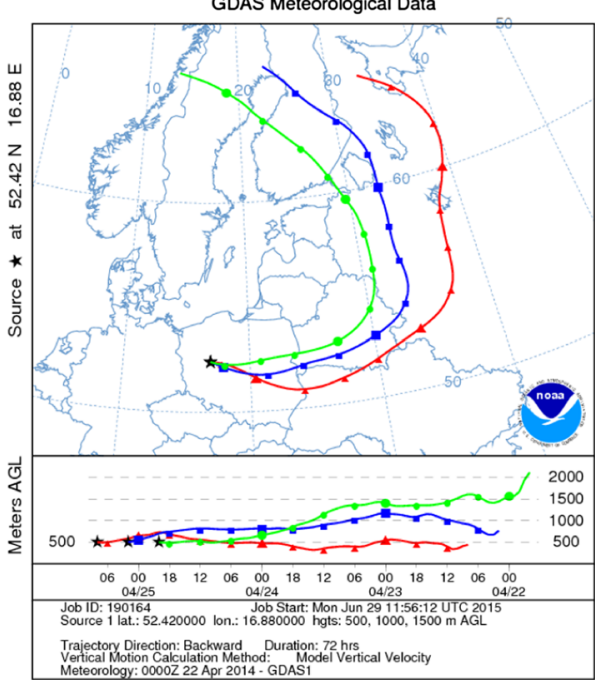


4 Fig. 3 Variation of $\mathrm{Hg}_{\mathrm{p}}$ concentrations in three clusters of air masses. a Cluster I and the 4-day backward trajectories for 16 June 2014. b Cluster II and the 4-day backward trajectories computed for Poznan during the episode of high $\mathrm{Hg}_{\mathrm{p}}$ on 14 January 2014. c Cluster III and the 4-day BT simulation for 25 April 2014. Blue bars represent $\mathrm{Hg}_{\mathrm{p}}$ values related to fine aerosol mode, whereas the gray ones reflect $\mathrm{Hg}$ in coarse particles

emission from regional anthropogenic sources. The monthly minimum of $\mathrm{Hg}$ bound to particles was found in August 2014. That decrease in total $\mathrm{Hg}_{\mathrm{p}}$ was pronounced in the midst of the growing season and was directly associated with much lower emissions from local/regional industrial sources. However, the contribution from other sources, e.g., emission from forest vegetation and soils, was significantly higher. Moreover, in the period from May to September 2014, very unstable atmospheric conditions (winds of $2-10 \mathrm{~m} / \mathrm{s}$ ) and large variability in monthly precipitation (between 13.2 and $84.7 \mathrm{~mm}$ ) were registered at the forest sampling site. This suggest that high-wind events $(>5 \mathrm{~m} / \mathrm{s})$ strongly impacted the monthly distribution of coarse and fine $\mathrm{Hg}$ at our forest site and caused lower variability of $\mathrm{Hg}$ in aerosol samples, probably due to greater dispersion effect or mitigation of locally emitted particles (dry deposition mechanism).

Interestingly, the largest discrepancies between $\mathrm{Hg}_{\mathrm{p}}$ concentrations measured in fine and coarse particles at the forest site were determined in March 2014, which indicated that the majority of $\mathrm{Hg}$ values obtained for Jeziory could presumably be attributed to different sources. These differences between $\mathrm{Hg}_{\text {coarse }}$ and $\mathrm{Hg}_{\text {fine }}$ could also be related to small-scale atmospheric processes (e.g., photochemical reactions on aerosol surface) or the increase in air/surface exchange of mercury vapor and other biogenic compounds such as low molecular weight organic acids over forest area. Furthermore, our second station was influenced by relatively low traffic emission (medium-traffic road approx. $4 \mathrm{~km}$ from the site) during the whole study period, which could explain low and stable $\mathrm{Hg}_{\text {fine }}$ concentrations.

\section{Particulate mercury concentration vs. long-range transport}

The spatial $\mathrm{Hg}_{\mathrm{p}}$ gradient observed in the present study highlighted the long-range atmospheric transport as a significant factor affecting seasonal variability of $\mathrm{Hg}$ compounds in the lower troposphere. The use of backward trajectories (BT) from the HYbrid Single-Particle Lagrangian Integrated Trajectory (HYSPLIT) model has become a popular method for interpretation of the results of particulate $\mathrm{Hg}$ measurements in relation to regional and global transport of polluted air masses (Li et al. 2008; Cheng et al. 2013; Feddersen et al. 2012; Siudek et al. 2014; Zhang et al. 2015). We examined only $\mathrm{Hg}_{\mathrm{p}}$ data obtained for the Poznań sampling site (in total 124 BTs) in 2014.
As a result, three different types of air masses were determined and linked to different clusters. The first cluster (N-NW wind sector, $45.2 \%$ of all BTs) represents clean air masses originating from the North Sea and the Atlantic Ocean, and then passing over relatively unpolluted northern European countries. The second cluster comprised of polluted air masses from western and southern European regions, particularly from France, Germany, Austria, Czech Republic, and northern Italy, where intensive industrial/urban activities occurred during the whole study period. In addition, the portion of air masses from Cluster II was associated with local and regional transport from western, southwestern, and southern Poland (Silesia region). These areas were recognized as regions which have a significant contribution to the seasonal pattern of high $\mathrm{Hg}_{\mathrm{p}}$ observed in Poznań. Trajectories taken into consideration in Cluster III (5.6 \% of all BTs simulations) were defined as mixed (sea-land) air masses and they were attributed to the transport over northeastern and eastern European regions.

Figure 3 illustrates the seasonal variability of particulate $\mathrm{Hg}$ concentrations within three clusters reflecting different air masses. The cluster analysis showed relatively various ranges of $\mathrm{Hg}_{\mathrm{p}}$ concentrations both in fine and coarse particles sampled in Poznań between January and October 2014. The monthly mean concentrations of coarse particulate mercury compared to $\mathrm{Hg}$ in fine particles were higher between January and April in all Clusters. At the beginning of the cold season (Jan-March), the elevated $\mathrm{Hg}_{\text {coarse }}$ concentrations were associated with western, southwestern, and southern air masses (Cluster II), suggesting that the aerosol population over our study domain was under the influence of numerous regional sources from the above sectors. For example, high total particulate mercury concentration $\left(76.5 \mathrm{pg} \mathrm{m}^{-3}\right)$ was determined on 14 January 2014 - the day when air masses were slowly transported (at relatively low altitude) from western parts of Europe, i.e., Germany, central UK, and northern Czech Republic, including highly polluted areas in southern Poland (Fig. 3b). Siudek et al. (2011) reported very similar episodes of elevated $\mathrm{Hg}$ concentrations in size-fractionated airborne particles in Gdynia (northern Poland), and indicated that industrial processes at a regional scale are a key factor. About $20 \%$ of $\mathrm{Hg}_{\mathrm{p}}$ data taken into account for the cold season (Jan-March) of 2014 in Poznań were additionally attributed to Cluster I, which suggested the significant influence of transboundary transport of $\mathrm{Hg}$ species from other anthropogenic sources located in NW-N regions. It should be also noted that due to proximity of the international airport Poznań-Ławica, aircraft emissions could have a significant impact on aerosol loadings and seasonal $\mathrm{Hg}_{\mathrm{p}}$ transformations in the boundary layer over our urban site. Pirrone et al. (2010) demonstrated a significant role of the civil aviation sector, especially the role of fuel combustion in the global Hg budget; however, they did not estimate its contribution to the total anthropogenic emission of $\mathrm{Hg}$. 
In addition, concentrations of coarse particulate mercury were also higher in samples collected in September and October (attributed to Cluster III). This observation suggests that coarse particles can be associated with different mechanical processes, mainly from anthropogenic sources during the heating season. Another possible explanation for seasonal differences in $\mathrm{Hg}$ concentration between coarse and fine particles was the impact of ambient temperature and aerosol composition on gas-partitioning of atmospheric mercury. Similar transformations were observed by other authors (Rutter and Schauer 2007; Zhu et al. 2014).

As presented in Fig. 3, Cluster I and II with trajectories computed for the warm season in 2014 (May to August) showed very similar trends (relatively low $\mathrm{Hg}_{\text {coarse }}$ and $\mathrm{Hg}_{\text {fine }}$ concentrations which did not exceed $10.0 \mathrm{pg} \mathrm{m}^{-3}$ ). This suggests the substantial decrease of local/regional anthropogenic emission in summer. On the other hand, an increase in fine particulate mercury concentration was observed between July and October, especially in Cluster II and III (Fig. 3). This indicates that such process as the adsorption of gaseous mercury onto submicron aerosols, which were produced by condensation/coagulation of pollutants during local/regional combustion processes, could be an important source of $\mathrm{Hg}$ in fine particles.

Based on NAAPS model results, it was found that during the measurements in spring (April) and fall (October) of 2014, several large wildfires in Eastern Europe occurred (Fig. 4). It seems that those events could have a potential effect on atmospheric conditions and climate in central Poland. A more recent work by Finley et al. (2009) showed that $15 \%$ of the total mercury released from regional wildfires could be found in particulate-phase $\mathrm{Hg}$ and, consequently, its contribution

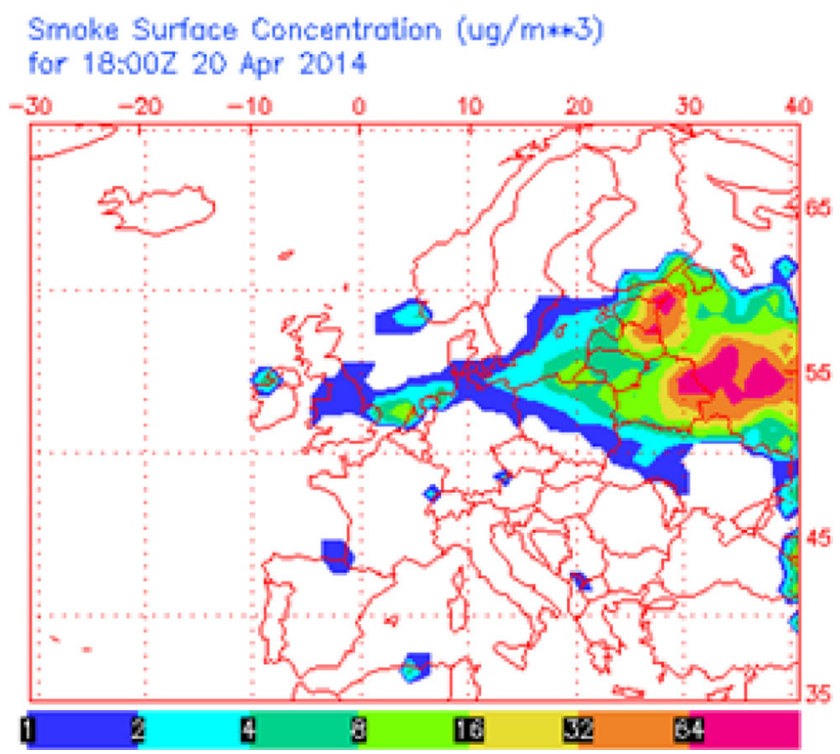

Fig. 4 Example of high emission of $\mathrm{S}$ compounds from a wildfire episode in Eastern Europe, April 2014 (NAAPS, Navy Aerosol Analysis and Prediction System) may be considered as a sign of anthropogenic emissions. Thus, the $\mathrm{Hg}_{\mathrm{p}}$ concentration of $54.7 \mathrm{pg} \mathrm{m}^{-3}$ measured on 20 April 2014 in Poznań could be partly attributed to the fire pollution episodes from eastern Ukraine, Russia, and Estonia, as shown in Figs. 3c and 4.

\section{Summary and conclusions}

In the present study, the concentrations of particulate mercury in the atmosphere were investigated using a filter pack method (without a $\mathrm{KCl}$ denuder), in the period between April 2013 and October 2014 at two sites in central Poland. The $\mathrm{Hg}$ concentrations in particulate matter in Poznań (urban area) were significantly higher than those reported in Jeziory (forest site). The median of $\mathrm{PHg}$ in urban fine particles was $4.0 \pm 9.1 \mathrm{pg} \mathrm{m}^{-3}$, whereas $\mathrm{Hg}$ in coarse aerosols was $16.4 \pm 45.3 \mathrm{pg} \mathrm{m}^{-3}$. Higher values of coarse $\mathrm{Hg}$ concentrations were observed during the episodes of winter pollution as compared to summer or spring measurements. The similar trend was found for $\mathrm{Hg}$ associated with fine aerosol fraction; however, the concentration range and variation were relatively lower. The seasonal variations of $\mathrm{Hg}$ in both the fractions at the urban site were higher than in the woodland protected area, which indicated a large influence of local anthropogenic sources. In this study, several factors, including air temperature, wind speed and direction, photochemistry, and precipitation amount, were identified as crucial for atmospheric transformations of $\mathrm{Hg}$ in particulate phase. During cold periods, low air temperature correlated well with elevated $\mathrm{Hg}_{\text {coarse }}$ concentrations, suggesting the predominance of gas-to-particle partitioning in the atmosphere. The main sources of $\mathrm{Hg}$ were determined based on meteorological analyses and backway trajectories. It was found that locally and regionally emitted $\mathrm{Hg}$ species significantly affected aerosol chemistry and properties within the examined urban-forest transect.

Acknowledgments This research was supported by the National Science Center in Poland (grant no. DEC-2012/04/S/ST10/00011). Special thanks to the NOAA Air Resources Laboratory for providing access to the HYSPLIT transport and dispersion model, and to the Botanic Garden in Poznan and the Ecological Station in Jeziory for providing the meteorological data. We also gratefully acknowledge the Naval Research Laboratory, Monterey, for the use of NAAPS model results.

Open Access This article is distributed under the terms of the Creative Commons Attribution 4.0 International License (http:// creativecommons.org/licenses/by/4.0/), which permits unrestricted use, distribution, and reproduction in any medium, provided you give appropriate credit to the original author(s) and the source, provide a link to the Creative Commons license, and indicate if changes were made. 


\section{References}

Beldowska M, Saniewska D, Falkowska L, Lewandowska A (2012) Mercury in particulate matter over Polish zone of the southern Baltic Sea. Atmos Environ 46:397-404

Bieser J, De Simone F, Gencarelli C, Geyer B, Hedgecock IM, Matthias V, Travnikov O, Weigelt A (2014) A diagnostic evaluation of modeled mercury wet deposition in Europe using atmospheric speciated high-resolution observations. Environ Sci Pollut Res 21:9995-10012

Cheng I, Zhang L, Blanchard P, Dalziel J, Tordon R (2013) Concentration-weighted trajectory approach to identifying potential sources of speciated atmospheric mercury at an urban coastal site in Nova Scotia, Canada. Atmos Chem Phys 13: 6031-6048

De Simone F, Gencarelli CN, Hedgecock IM, Pirrone N (2014) Global atmospheric cycle of mercury: a model study on the impact of oxidation mechanisms. Environ Sci Pollut Res 21:4110-4123

Draxler RR, Rolph GD (2003) HYSPLIT (HYbrid single-particle lagrangian integrated trajectory) model access via NOAA ARL READY website. NOAA Air Resources Laboratory, Silver Spring. http://www.arl.noaa.gov/ready/hysplit4.html

Ebinghaus R, Tripathi RM, Wallschaläger D, Lindberg SE (1999) Natural and anthropogenic mercury sources and their impact on the airsurface exchange of mercury on regional and global scales. In: Ebinghaus R, Turner RR, de Lacerda LD, Vasiliev O, Salomons W (eds) Mercury contaminated sites - characterization, risk assessment and remediation. Springer, Berlin

Fang FM, Wang QC, Li JF (2004) Urban environmental mercury in Changchun, a metropolitan city in northeastern China: source, cycle and fate. Sci Total Environ 330:159-170

Fang G-C, Yang I-L, Liu C-K (2010) Estimation of atmospheric particulates and dry deposition particulate-bound mercury $\mathrm{Hg}(\mathrm{p})$ in Sha-Lu, Taiwan. Aerosol Air Qual Res 10:403-413

Feddersen DM, Talbot R, Mao H, Sive BC (2012) Size distribution of particulate in marine and coastal atmospheres. Atmos Chem Phys 12:10899-10909

Finley BD, Swartzendruber PC, Jaffe DA (2009) Particulate mercury emissions in regional wildfire plumes observed at the Mount Bachelor Observatory. Atmos Environ 38:6074-6083

Fu X, Feng X, Qiu G, Shang L, Zhang H (2011) Speciated atmospheric mercury and its potential sources in Guiyang. China Atmos Environ 45:4205-4212

Gencarelli CN, De Simone F, Hedgecock IM, Sprovieri F, Pirrone N (2014) Development and application of a regional-scale atmospheric mercury model based on WRF/Chem: a Mediterranean area investigation. Environ Sci Pollut Res 21:4095-4109

Jen Y-H, Chen W-H, Yuan C-S, Ie I-R, Hung C-H (2014) Seasonal variation and spatial distribution of atmospheric mercury and its gasparticulate partition in the vicinity of a semiconductor manufacturing complex. Environ Sci Pollut Res 21:5474-5483

Kim P-R, Han Y-J, Holsen TM, Yi S-M (2012) Atmospheric particulate mercury: concentrations and size distribution. Atmos Environ 61: 94-102

Landis M, Stevens R, Schaedlich F, Prestbo E (2002) Development and characterization of an annular denuder methodology for the measurement of divalent inorganic reactive gaseous mercury in ambient air. Environ Sci Technol 36:3000-3009

Li J, Sommar J, Wängberg I, Lindqvist O, S-q W (2008) Short-time variation of mercury speciation in the urban of Göteborg during GÖTE-2005. Atmos Environ 42:8382-8388

Lindberg S, Bullock R, Ebinghaus R, Engstrom D, Feng X, Fitzgerald W, Pirrone N, Prestbo E, Seigneur C (2007) A synthesis of progress and uncertainties in attributing the sources of mercury in deposition. Ambio 36:19-32
Liu B, Keeler GJ, Dvonch JT, Barres JA, Lynam MM, Marsik FJ, Morgan JT (2010) Urban-rural differences in atmospheric mercury speciation. Atmos Environ 44:2013-2023

Lu JY, Schroeder WH, Berg T, Munthe J, Schneeberger D, Schaedlich F (1998) A device for sampling and determination of total particulate mercury in ambient air. Anal Chem 70:2403-2408

Lynam MM, Keeler GJ (2002) Comparison of methods for particulate phase mercury analysis: sampling and analysis. Anal Bioanal Chem 374:1009-1014

Lynam MM, Keeler GJ (2005) Artifacts associated with the measurement of particulate mercury in an urban environment: the influence of elevated ozone concentrations. Atmos Environ 39:3081-3088

Lynam MM, Keeler GJ (2006) Source-receptor relationships for atmospheric mercury in urban Detroit, Michigan. Atmos Environ 40: 3144-3155

Lynam MM, Dvoch JT, Hall NL, Morishita M, Barres JA (2014) Spatial patterns in wet and dry deposition of atmospheric mercury and trace elements in central Illinois, USA. Environ Sci Pollut Res 21:4032-4043

Pacyna EC, Pacyna JM, Sundeseth K, Munthe J, Kindbom K, Wilson S, Steenhuisen F, Maxson P (2010) Global emission of mercury to the atmosphere from anthropogenic sources in 2005 and projections to 2020. Atmos Environ 44:2487-2499

Pirrone N, Cinnirella S, Feng X, Finkelman RB, Friedli HR, Leaner J, Mason R, Mukherjee AB, Stracher GB, Streets DG, Telmer K (2010) Global mercury emissions to the atmosphere from anthropogenic and natural sources. Atmos Chem Phys 10:5951-5964

Poissant L, Pilote M, Beauvais C, Constant P, Zhang HH (2005) A year of continuous measurements of three atmospheric mercury species (GEM, RGM and Hgp) in southern Quebec, Canada. Atmos Environ 7:1275-1287

Pyta H, Rosik-Dulewska C, Czaplicka M (2009) Speciation of ambient mercury in the Upper Silesia Region, Poland. Water Air Soil Pollut 197:233-240

Rothenberg SE, McKee L, Gilbreath A, Yee D, Connor M, Fu X (2010) Evidence for short-range transport of atmospheric mercury to a rural, inland site. Atmos Environ 44:1263-1273

Rutter AP, Schauer JJ (2007) The impact of aerosol composition on the particle to gas partitioning of reactive mercury. Environ Sci Technol 41:3934-3939

Rutter AP, Snyder DC, Stone EA, Schauer JJ, Gonzalez-Abraham R, Molina LT, Márquez C, Cádenas B, de Foy B (2009) In situ measurements of speciated atmospheric mercury and the identification of source regions in the Mexico City Metropolitan Area. Atmos Chem Phys 9:207-220

Schroeder WH, Munthe J (1998) Atmospheric mercury—an overview. Atmos Environ 32:809-822

Seo Y-S, Han Y-J, Choi H-D, Holsen TM, Yi S-M (2012) Characteristics of total mercury (TM) wet deposition: scavenging of atmospheric mercury species. Atmos Environ 49: 69-76

Siudek P, Falkowska L, Urba A (2011) Temporal variability of particulate mercury in the air over the urbanized coastal zone of the southern Baltic. Atmos Pollut Res 2:484-491

Siudek P, Falkowska L, Frankowski M, Siepak J (2014) An investigation of atmospheric mercury accumulated in the snow cover from the urbanized coastal zone of the Baltic Sea, Poland. Atmos Environ 95:10-19

Siudek P, Falkowska L, Brodecka A, Kowalski A, Frankowski M, Siepak $\mathrm{J}$ (2015) Mercury in precipitation over the coastal zone of the southern Baltic Sea, Poland. Environ Sci Pollut Res 22:2546-2557

Song XJ, Cheng I, Lu J (2009) Annual atmospheric mercury species in downtown Toronto, Canada. J Environ Monit 11:660-669 
Steffen A, Bottenheim J, Cole A, Ebinghaus R, Lawson G, Leaitch WR (2014) Atmospheric mercury speciation and mercury in snow over time at alert. Can Atmos Chem Phys 14: 2219-2231

US EPA (2002) Method 1631: revision E. Mercury in water by oxidation, purge and trap, and cold vapor atomic fluorescence spectrometry. US EPA:1-33

Wan Q, Feng XB, Lu J, Zheng W, Song XJ, Han SJ, Xu H (2009) Atmospheric mercury in Changbai Mountain area, northeastern China II. The distribution of reactive gaseous mercury and particulate mercury and mercury deposition fluxes. Environ Res 109:721-727

Wang Z, Zhang X, Chen Z, Zhang Y (2006) Mercury concentrations in size-fractionated airborne particles at urban and suburban sites in Beijing, China. Atmos Environ 40:2194-2201

Weigelt A, Temme C, Bieber E, Schwerin A, Schuetze M, Ebinghaus R, Kock HH (2013) Measurements of atmospheric mercury species at a German rural background site from 2009 to 2011 -methods and results. Environ Chem 10:102-110

WIOŚ (Voivodship Inspectorate for Environmental Protection) (2013) Report on the state of the environment in Wielkopolska district in 2013 (in Polish):1-138
Xiu CJ, Cai J, Zhang WY, Zhang DN, Büeler A, Lee SC, Shen Y, Xu L, Huang X, Zhang P (2009) Speciated mercury in sizefractionated particles in Shanghai ambient air. Atmos Environ 43:3145-3154

Xu L, Chen J, Yang L, Niu Z, Tong L, Yin L, Chen Y (2015) Characteristics and sources of atmospheric mercury speciation in a coastal city, Xiamen, China. Chemosphere 119:530-539

Zhang X, Siddiqi Z, Song X, Mandiwana KL, Yousaf M, Lu J (2012) Atmospheric dry and wet deposition of mercury in Toronto. Atmos Environ 50:60-65

Zhang Y, Liu R, Wang Y, Ciu X, Qi J (2015) Change characteristic of particulate mercury during dust weather of spring in Qingdao, China. Atmos Environ 102:376-383

Zhu J, Wang T, Talbot R, Mao H, Yang X, Fu C, Sun J, Zhuang B, Li S, Han Y, Xie M (2014) Characteristics of atmospheric mercury deposition and size-fractionated particulate mercury in urban Nanjing, China. Atmos Chem Phys 14:2233-2244

Zielonka U, Hławiczka S, Fudała J, Munthe J (2005) Seasonal mercury concentrations measured in rural air in southern Poland, contribution from local and regional coal combustion. Atmos Environ 39:7580-7586 